\title{
Una mirada lejana
}

\section{Luis Montiel (*)}

(*) Historia de la Ciencia. Universidad Complutense de Madrid

Dynamis

[0211-9536] 2011; 31 (1): 241-243

Los editores de Dynamis me invitan a redactar unas líneas sobre la figura - a la persona la traté muy poco- de José María López Piñero, lo que hace que me sienta a la vez honrado y amedrentado; amedrentado porque, como acabo de afirmar, mi trato con el maestro de historiadores de la medicina y de la ciencia fue esporádico y poco profundo, y mi relación con su obra escasa; honrado porque su valía científica, su condición de maestro, no se me escapan a pesar de lo anterior, como no se me oculta su importancia en la expansión y la consolidación de la Historia de la medicina y de la ciencia en España. Por ello, como tan a menudo - por desgracia- ocurre, lamento ahora no haber llegado a conocerle mejor, no tanto por poder redactar con mejores títulos esta breve nota cuanto por haber llegado a saber, como supe acerca de Pedro Laín, qué podía decirme precisamente a mí su manera de entender su quehacer profesional y su misión como docente en una facultad de Medicina. Ya es tarde para eso, de modo que acaso sirva para justificar mi presencia en esta sección de la revista precisamente mi condición de foráneo, de extranjero. Escribiré sobre López Piñero como los persas de Montesquieu sobre los europeos - en particular los franceses-, o como aquél Oskar Matzerath que nunca crecía y llevaba como insignia un tambor de hojalata sobre el mundo de los adultos.

La primera imagen que, a través de terceros, tuve de José María López Piñero fue la de un líder: alguien que tenía un proyecto, un propósito; personas con las que ponerlo en marcha y la decisión necesaria para llevarlo a efecto; imagen que presentaba, huelga decirlo, zonas de sombra. De hecho la primera experiencia que tuve de esa parte tan especial de la vida universitaria que es la conquista de las plazas vino marcada por la sensación, real o ficticia, de que precisamente su sombra se cernía sobre el theatrum academicum, sit venia verbo. 
Así son las cosas. Más tarde he visto otras sombras y me pregunto cada día, aunque sospecho que mis circunstancias me impedirán ponerme a prueba, si no veré algún día proyectarse la mía, con largas uñas de rapaz, sobre una pared, como la del Nosferatu de Murnau. Al fin y al cabo éste necesitaba la tierra de Transilvania para vivir, de modo que hay que pensar que, del mismo modo que «algo tendrá el agua cuando la bendicen», algo tiene el medio, el terruño universitario, cuando los más prudentes debemos pensar en vacunarnos.

El caso es que López Piñero dejó una escuela, cosa que pocos pueden decir. Y esa escuela, cada vez más amplia y ramificada, está, a mi parecer, muy viva y en algún caso notablemente injertada en la sociedad, permitiendo que cuando alguien pregunta, refiriéndose a la Historia de la medicina, por quién doblan las campanas podamos responder: «honradamente, no tengo ni idea».

Otra cosa tengo clara en mi condición de «persa»: López Piñero practicó y transmitió un modo de hacer historia de la medicina irreprochable, de manera que incluso quienes venimos de otros territorios no podemos por menos de adoptar esa solidez, ese rigor y ese enfoque. Y digo «venimos» porque no siempre vivimos en ellos. Meteco respecto del ambiente de López Piñero hace ya tiempo que dejé de serlo en el mundo de la Historia de la medicina; precisamente desde que conseguí mi primera plaza de numerario. En aquel concurso era yo, con todas las de la ley - de extranjería- un «persa», y en el tribunal estaba José María López Piñero. Ya he dicho en elipsis que la cosa terminó bien, aunque con un mensaje que me hizo llegar Laín, presente también en aquél tribunal: lo que hacía yo en mi tierra estaba bien, pero además había que hacer historia de la medicina. Creo haber sido obediente y cada vez estoy más satisfecho de ello. Recuerdo con agrado el momento, reciente, en el que Esteban Rodríguez Ocaña me dijo: «te hicimos un favor al convertirte en historiador de la medicina», frase seguida por otra que ahora no viene al caso. Convengo en ello, y brevemente explicaré por qué.

Creo que la de médico es una profesión valiosa, que con el tiempo - con la historia - se ha ido convirtiendo en eficaz. Esto sería muy bueno si no implicara el riesgo de que su valor se redujera a la eficacia. Y quien siendo médico e historiador trabaja en una Facultad de medicina tiene, pienso yo, la idea de que es esto lo que precisamente está ocurriendo. Del «je le pansay et Dieu le guaris»" de Paré algunos - no todos- han pasado, en nombre - profanado- de la ciencia al dominio de las «vidas sin valor», 
y quién sabe qué cosas podemos ver todavía. Si no fuera por la historia, especialmente cuando se hace de determinada manera, los médicos del siglo veintiuno no recibirían otra formación que la estrictamente biológica, remendada con alguna prótesis humanística abrumadoramente tecnificada, para que no desentone. Para quien tiene vocación de meteco es toda una oportunidad poder decirles a los médicos cómo los ve un «persa», y algunos de ellos llegan a reflexionar. De eso se trata: de contar la historia en tanto que historia, lo que hicieron tanto López Piñero como Laín, sin pretensiones de buscar ningún pacto con el vecino poderoso; y en el caso del primero, con esa voluntad de crítica que, pienso yo, quienes somos más jóvenes que él hemos adoptado, cada cual a su particular manera. ¡Qué jocosa aceptación despertó en mí, por ejemplo, aquella afirmación suya que figura al comienzo de su Introducción a la medicina sobre la inutilidad del invasivo idioma inglés para reflexionar acerca de las cosas realmente serias en nuestra disciplina!

Una historia para poner en cuestión lo que se da por intocable, difícil de rechazar en nombre de cualquier posible falta de rigor, partera de ideas nuevas, vacuna del cientismo: legado que hasta un persa aceptaría con gusto para ser menos persa y para que los franceses sean menos franceses. 
